\title{
Factors Affecting Capacity Utilization Decisions in Nigeria: A Time Series Analysis
}

\author{
Mojekwu, J. N. \\ Department of Actuarial Science and Insurance \\ University of Lagos, Akoka, Lagos. Nigeria \\ Tel: 234-803-306-3363 E-mail: jnmoj@yahoo.com
}

Iwuji, I. I.

Department of Business Administration,

University of Lagos, Akoka, Lagos, Nigeria

Tel: 234-805-119-7460Ｅ-mail: iwujiifeanyi@yahoo.co.uk

Received: July 11, 2011

doi:10.5539/ibr.v5n1p157
Accepted: September 8, 2011

Published: January 1, 2012

URL: http://dx.doi.org/10.5539/ibr.v5n1p157

\begin{abstract}
This study examined the impact of some macroeconomic variables and power supply on the performance of the Nigerian manufacturing sector, using ex-post facto research design. Secondary data were sourced from Central Bank of Nigeria (CBN) statistical bulletin (2009) and other publications. The main findings of the study were that power supply had positive and significant impact on capacity utilization while inflation rate and interest rate had negative impact on capacity utilization. However, the impact of interest rate was significant at $5 \%$ level while lending rate was insignificant. Time series data were analysed with the aid of e-views 5.0 econometric computer package using least square multiple regression technique. The regression model explained $88.54 \%$ of the variation in capacity utilization, after correcting for linearity, normality, auto-correlation and heteroscedascity. The study recommended that the ongoing privatisation of Power Holding Company of Nigeria should be pursued with vigour and that the policy thrust of single digit inflation and lending rates by CBN should be sustained. The government should also put in place monetary and fiscal policies to create an enabling environment for the manufacturing sector, thereby giving a boost to the economy as a whole.
\end{abstract}

Keywords: Nigerian manufacturing sector, Capacity utilization, Multiple regression, Autoregressive Model, Co-integration

\section{Introduction}

The problem of the Nigerian Manufacturing sector started in 1970s which corresponded with sharp increase in the international oil price. The government responded with the import substitution strategy aimed at increasing domestic production. There was huge investment in state owned enterprises. The contribution of manufacturing to GDP rose from 2\% in 1957 to $7 \%$ in 1967. Like in most countries in Africa, the import substitution strategy failed to generate income and employment growth. (Soderbom \& Teal, 2002). Following the fall in oil prices in late 1970s and early 1980s the economy went into rapid decline. To avert catastrophic collapse of the economy, the government introduced tough budgetary and fiscal measures, involving deregulation of foreign exchange market, abolition of import licenses, and devaluation of the naira. The effect of these policy measures were nothing to cheer about as the economy took further steps backward, with its attendant miseries on the populace. To stimulate domestic production the structural adjustment programme (SAP) was initiated in 1986. SAP brought with it escalation in exchange rate resulting in high cost of raw materials and spare parts. The SAP programme ended up being a failure. The harsh economic situation triggered a chain reaction, such as high cost of production, scarcity of raw materials and spare parts and huge inventory of unsold goods due to low purchasing power. All these factors impacted negatively on capacity utilisation. (Banjoko, 2002).

Current governmental programmes aimed at reversing the economic trend are National economic empowerment and development (NEEDS) and vision 2020, which according to the proponents will put Nigeria among the first twenty (20) developed economies by the year 2020. It is against this background that it becomes imperative to access the 
effects of power supply and some macroeconomic variables on capacity utilization of the Nigerian manufacturing industry, thereby providing policy recommendations to the policy makers. The objectives of the study are:

- To assess the impact of power supply on capacity utilization of the Nigerian Manufacturing industry.

- To evaluate the effects of inflation rate on capacity utilization of the Nigerian Manufacturing industry.

- To examine the relationship between capacity utilization rate and interest rate in Nigerian Manufacturing industry.

In order to achieve the above objectives, the following hypotheses were proposed for testing.

- Power supply will not have significant effect on capacity utilization decisions in Nigeria.

- Inflation rate will not have significant effect on capacity utilization decisions in Nigeria.

- Interest rate will not have significant effect on capacity utilization decision in Nigeria.

\section{Literature Review}

According to Slack et al (2007) capacity utilization is defined as the ratio of actual output to design capacity, symbolically it is expressed as:

$$
\mathrm{CU}=\mathrm{A}_{\mathrm{c}} * 100 / \mathrm{D}_{\mathrm{c}}
$$

Where $\mathrm{CU}=$ Capacity Utilization, $\mathrm{A}_{\mathrm{c}}=$ Actual output, $\mathrm{D}_{\mathrm{c}}=$ Design capacity

Design capacity is the capacity the technical designers have in mind when the operation was commissioned. It is hardly achievable in real life due to both planned and unplanned stoppages. The planned stoppages include set up, preventive maintenance, no work scheduled, quality sampling checks, shift change times etc. The unplanned stoppages include equipment breakdown, quality failure investigation, material stock outs, labour shortages and waiting for materials. The planned stoppages are unavoidable, while the unplanned are avoidable. In computing the actual output, both planned and unplanned stoppages must be deducted from the design capacity.

The influence of some macroeconomic factors as predictors of capacity utilization has been well documented by scholars (Eniola, 2009; Adenekan 2010). The macroeconomic variables identified include; inflation rate, real exchange rate real loans and advances, ratio of import of manufactures to GDP , ratio of federal government expenditures to GDP and ratio of foreign direct investment on GDP.

\subsection{Power Supply}

The work of Siyan and Ekhator (2001) gave an insight into the gross inefficiency that characterized most public enterprises like the National Electric Power Authority (NEPA) now Power Holding Company of Nigeria (PHCN). The study revealed that the installed capacity of NEPA in the 1980s was $6000 \mathrm{MW}$ but by 1990 , the available installed capacity dropped to less than 2000MW and has continued to drop since then. Some of the plants which were available in 1980s were no longer available by 1990. The main reasons for the continued drop being inefficiency and corruption (see appendix 1). Table 1 shows that, in 1980 there were a total of 76 installed units with total capacity of $6000 \mathrm{MW}$, but by 2001 only 22 units were available with total capacity of $2716.6 \mathrm{MW}$ and actual capacity generated being $2278 \mathrm{MW}$. There was $338.6 \mathrm{MW}$ of generation loss from available capacity. At Sapele station for example only two (2) generating units were available in 2001 out of the ten (10) installed in 1980. Available capacity was $360 \mathrm{MW}$ in 2001 while actual available capacity was $253 \mathrm{MW}$ representing a generating loss of $107 \mathrm{MW}$.

\section{Insert Table 1 Here}

\subsection{Interest Rate}

When banks lend money to a manufacturer, they use depositor's money. The interest charged, which currently is about $25 \%$ of the principal is made up of two components, $5 \%$ to depositors and $20 \%$ to cover bank overhead and profit. If this interest is too high as is the case in Nigeria, production cost will also increase and impact negatively on capacity utilization. The negative impact of lending rate is well established in literature.

\subsection{Inflation Rate}

According to Umo (2007), inflation can be defined as a generalized increase in the level of prices sustained over a long period of time. From, the definition, inflation is a macroeconomic phenomenon and does not refer to specific products whose prices may fall or rise during the period under consideration. In other words, it refers to the aggregate or basket of goods. It is measured as a ratio of the increase in aggregate price and aggregate price at the base period. It is usually expressed in percentage. 
Eniola (2009) reported that Exchange rate, Inflation rate, Imports Federal capital expenditure, foreign direct investment (FDI) and Real loans and advances accounted for 50 percent variation in capacity utilization. Out of the six variables only inflation rate had a negative impact on capacity utilization while the other five had positive impact. The finding also revealed that there was a very strong positive and significant relationship between imported manufactures and capacity utilization, showing that Nigeria is highly important dependent. From the study 1percent change in imported manufactures resulted in 18.33 percent increase in capacity utilization, indicating that Nigeria is highly important dependent.

\section{Data and Methodology}

The study method used is ex-post facto design using 1981 - 2009 data sourced from CBN statistical bulletin and other publications to access the impact of power supply, inflation rate and interest rate on capacity utilization rate.

The data analysis was carried out using ordinary least square (OLS) multiple regression technique. Log transformations of the variables were carried out to improve linearity.

Insert Table 2 Here

\subsection{Model Specifications}

The following model specifications which were estimated with the aid of e-views 5.0 statistical package are as follows.

Model 1 - At level:

$$
\log \left(\mathrm{cu}_{\mathrm{t}}\right)=\beta_{1}+\beta_{2} \log \left(\mathrm{elec}_{\mathrm{t}}\right)+\beta_{3} \log \left(\text { inf }_{\mathrm{t}}\right)+\beta_{4} \log \left(\text { int }_{\mathrm{t}}\right)+\mu_{\mathrm{t}}
$$

Model 2 - including one period lags of variables as independent variables

$$
\begin{gathered}
\log \left(\mathrm{cu}_{\mathrm{t}}\right)=\beta_{1}+\beta_{2} \log \left(\text { elec }_{\mathrm{t}}\right)+\beta_{3} \log \left(\text { inf }_{\mathrm{t}}\right)+\beta_{4} \log \left(\text { int }_{\mathrm{t}}\right)+\beta_{5} \log (\mathrm{cu}(-1))+ \\
\beta_{6} \operatorname{logelec}(-1)+\beta_{7} \log (\inf (-1))+\beta_{8} \log (\operatorname{int}(-1))+\mu_{\mathrm{t}}
\end{gathered}
$$

Model 3 - Auto regressive (AR) model

$$
\begin{gathered}
\log \left(\mathrm{cu}_{\mathrm{t}}\right)=\beta_{1}+\beta_{2} \log \left(\text { elec }_{\mathrm{t}}\right)+\beta_{3} \log \left(\mathrm{inf}_{\mathrm{t}}\right)+\beta_{4} \log \left(\text { int }_{\mathrm{t}}\right)+\mu_{\mathrm{t}} \\
\mu_{\mathrm{t}}=\mu_{\mathrm{t}-1}+\mathrm{e}_{\mathrm{t}}
\end{gathered}
$$

Where $\mathrm{cu}=$ capacity utilization $(\%)$, elec $=$ Electricity generated in megawatts,

inf $=$ inflation rate $(\%)$, int $=$ interest rate $(\%)$, and $t=$ time period. To diagnose and control the assumptions of the regression modeling the following tests were carried out on the variables as well as the residual. Normality, Augumented Dickey-fuller (ADF) Unit root test, Breusch-Godfery LM test for serial correlation of the residuals and Autoregressive conditional Heteroscedasticity (ARCH) test for non-constant variance of the error term. The e-views 5.0 outputs is as shown in table 3.

The corresponding Substituted Coefficients for models 1, 2, and 3 respectively are shown below:

$$
\begin{aligned}
& \log (\mathrm{cu})=1.517555446+0.4326251015 * \log (\mathrm{elec})-0.01953631977 * \log (\mathrm{inf})- \\
& \quad 0.3282804849 * \log (\text { int })
\end{aligned}
$$

$\log (\mathrm{cu})=-0.3753031584+0.06881104735 * \log (\mathrm{elec})-0.01503188026 * \log ($ inf $)+0.1878999709 * \log ($ inf $)+0$. $8005849346 * \log (\mathrm{cu}(-1))+0.05990645918 *$

$\log ($ elec $(-1))-0.04458446685 * \log (\inf (-1))-0.08792852816 * \log (\operatorname{int}(-1))$

$\log (\mathrm{cu})=2.562322934+0.09154993813 * \log (\mathrm{elec})+0.005186872855 * \log (\mathrm{inf})+$

$$
0.1366020106 * \log (\text { int })+[\operatorname{AR}(1)=0.8105415303]
$$

\section{Discussion}

From the ADF tests only log (inf) is stationary at I (0) level of integration or differencing and $5 \%$ level of significance, while $\log (\mathrm{cu}), \log (\mathrm{elec})$, and $\log$ (int) are non-stationary. The unrestricted co-integration Rank test (trace) result indicates two co-integrating equations at 0.5 levels. The implication of this though the series are individually non-stationary, they are co-integrated. Model 1, therefore is not spurious or nonsense. (Gujarati, 1999; Alao, 2010; Hossain, 2009; Nahmias, 2001; Engle and Granger, 1987). Model 2 and 3 are an improvement over model 2 and 3 by including one period lags or the error term respectively as independent variables. This addressed the problems of serial correlation, stationarity, heteoscedasticity etc .From table 3, it is evident that models 2 and 3 showed drastic improvement in all dimensions over model 1, including Dubin-watson statistic for serial correlation, coefficient of determination which measures the variation in $\log (\mathrm{cu})$ explained by the the model, Standard error 
which measures the error of forecast of the model, and other indicators. The coefficient of determination improved from $29.9 \%$ for model 1 to $84.5 \%$ and $82.7 \%$ for models 2 and 3.respectively.

Insert Table 4 \& Table 5 Here

From the substituted coefficients for model 1 , an increase of 1 unit of $\log$ (elec) that is, e $1=2.72$ megawatts generated will be accompanied by an increase of

$\mathrm{e}^{0.432526}=1.54 \%$ in capacity utilization holding other variables constant.

The overall impact of the three models is significant as measured by Prob (F-statistics). In practice it is possible to have a situation where the variables have significant impact individually but when taken together the impact might be low as a result of high interaction or correlation among the variables.

From the Wald test electricity supply has a significant positive impact on capacity utilisation at $5 \%$ level of significance, while inflation rate and interest rate have negative impact. The impact of interest rate is significant at a p-value of 0.0212 and 0.039 for F-Statistics and $\mathrm{x}^{2}$ statistic respectively. The impact of inflation is negative as expected but not significant at $5 \%$ level. The effect of interest rate being negative is expected because it has direct relationship with high production cost which lowers capacity utilization. The effect of electricity is understandable because when the machines are idle production shutdown.

\section{Conclusion}

It is strongly recommended that PHCN should be privatized without further delay. The issue of improved power supply as a strategy aimed at boosting o capacity utilization of the manufacturing sector and the economy as a whole cannot be emphasized. A situation where PHCN had an installed and available capacity of 6000MW in 1980 but is struggling to generate $1500 \mathrm{MW}$ of electricity in 2011 is by all known standards an abysmally poor performance. Borrowing from the experience of China where power generation is decentralized the independent power supply strategy has to be vigorously pursued. In addition to hydroelectricity the time has come for us to consider in our National strategic plans, other options in addition to gas as source of power for the turbines. The alternative sources include the use of coal, wind, bio-fuel and solar energy.

The present policy of CBN to keep inflation and interest rate at single digit level should be vigorously pursued. The study clearly shows that both variables impact negatively on capacity utilization.

The government should always consider the findings and recommendations of researchers and captains of industry in crafting policies.

The government should also constitute a committee where all stakeholders including manufacturers will be fully represented. The committee should be headed by the Head of State so that the committee's recommendations could have an eye on implementations against what obtained in the past where committee recommendations had no executive backing.

The government should also set specific targets for the manufacturing sector in the implementation plan of vision 2020. For example there is no reason capacity utilization should not increase from present level of $35 \%$ to $65 \%$ by 2015. This is achievable if the present level of power generation of $1500 \mathrm{MW}$ is increased to $15,000 \mathrm{MW}$ by 2015 .

From the findings and policy recommendations, the role of the government in cushioning the effects of epileptic power supply and other macroeconomic variables on capacity utilization cannot be overemphasized. The government should put in place appropriate macroeconomic policies to improve the performance of the manufacturing industry. This is important if the noble objective of vision 2020 of Nigeria being counted among the first twenty industrialized economies of the world by the year 2020 is to be realized.

\section{References}

Adenekan, S. (2010). Low Capacity Utilisation, Bane of the Nigerian Manufacturing Sector. [Online] Available: http://www.punchng.com/Articl.aspx?theartic=Art201001072339196. (January 8, 2010)

Alao, B. O. (2010). Productivity in the Nigerian Manufacturing Sub- Sector: An Error Correction Model (ECM). Journal of Economics, Finance and Administrative Sciences, 20, 1450-2275.

Banjoko, S. A. (2002). Production and Operations Management. Nigeria: Pumark Nigeria Limited.

Dickey, D. A., \& Fuller, W. A. (1979). Distribution of the Estimators for Autoregressive Time Series with a unit Root. Journal of the American Statistical Association, 74, 427 - 431. http://dx.doi.org/10.2307/2286348

Engle, R. F., \& Granger, C. W. J. (1987). Co-intgegration and Error Correction Representations, Estimation and Testing. Econometrica, 251-76. http://dx.doi.org/10.2307/1913236 
Enimola, S. S. (2009). The Determinants of Capacity Utilization in Nigeria Manufacturing Industry. Journal of Economic Thought, 3(1), 57- 63

Gujarati, D. N. (1999). Essentials of Econometrics, McGraw-Hill Internationa, (2nd ed.). New York. (chapters 1114).

Mackinnon, J. G. (1996). Numerical Distribution Functions for Unit root and Co-integration Tests. Journal of $\begin{array}{llllll}\text { Applied } & \text { Econometrics, } & 11, & 601 & - & 618 .\end{array}$ http://dx.doi.org/10.1002/(SICI)1099-1255(199611)11:6<601::AID-JAE417>3.0.CO;2-T.

Nahmias, S. (2001). Production and Operations Management. (4th ed.). New York: McGraw-Hill .

Siyan, P., \& Ekhator,V. (2001). Restructuring The Nigerian Economy Through The Privatisation of Public Enterprises: An Impact Analysis of the National Electric Power Authority (NEPA) (2001). Daily Broadcast, National Control Centre, Oshogbo, Nigeria. Lagos Organisation Review 32, LOR Feature 2.

Slack, N., Chambers, S., \& Johnston, R. (2008). Operations Management. (5th ed.). UK: Prentice Hall.

Soderbom, M; \& teal, F. (2002). The Performance of Nigerian Manufacturing Firms: Report on the Nigerian Manufacturing Enterprise Survey 2001. UK: Centre for the Study of African Economies University of Oxford.

Umo, J. U. (2003). Practical Microeconomic Analysis in African Context. Nigeria: Netlink research Consult Ltd. Ebute Metta, Lagos.

Table 1. Power Stations in Nigeria and their Generation Capacities

\begin{tabular}{|c|c|c|c|c|c|c|}
\hline $\mathrm{S} / \mathrm{N}$ & Station & Installed unit & Available unit & $\begin{array}{c}\text { Installed Available Unit } \\
(\mathrm{MW})\end{array}$ & $\begin{array}{l}\text { Actual Capacity Generated } \\
(\mathrm{MW})\end{array}$ & $\begin{array}{c}\text { Generation Loss } \\
(\mathrm{MW})\end{array}$ \\
\hline 1 & Kanji & 8 & 3 & 260 & 186 & 74 \\
\hline 2 & Jebba & 6 & 4 & 385.6 & 269 & 16.6 \\
\hline 3 & Shiroro & 4 & 2 & 450 & 425 & 25 \\
\hline 4 & Egbin & 6 & 3 & 880 & 825 & 57 \\
\hline 5 & Sapele & 10 & 2 & 360 & 253 & 107 \\
\hline 6 & Afam & 18 & 3 & 40 & 30 & 101 \\
\hline 7 & Delta & 20 & 3 & 320 & 291 & 29 \\
\hline 8 & Ijora & 3 & 1 & 20 & 0 & 20 \\
\hline \multirow[t]{2}{*}{9} & Calabar & 1 & 1 & 1 & 1 & 0 \\
\hline & Total & 76 & 22 & 2716.6 & 2278 & 338.6 \\
\hline
\end{tabular}

Source: Daily Broadcast, national Control Centre, Oshogbo, 2000 as Reported by Siyan and Ekhator (2001) 
Table 2. Annual Capacity Utilization Rates, Electricity Generation, GDP, Inflation and Interest Rates

\begin{tabular}{|c|c|c|c|c|c|}
\hline Year & $\begin{array}{l}\text { MANUFACTURING } \\
\text { CAPACITY } \\
\text { UTILIZATION RATE } \\
(\%) \\
\end{array}$ & $\begin{array}{c}\text { ELECTRICITY } \\
\text { GENERATION IN } \\
\text { MEGAWATTS (MW) }\end{array}$ & $\begin{array}{c}\text { GROSS DOMESTIC } \\
\text { PRODUCT AT } 1990 \text { BASIC } \\
\text { PRICES (MILLIONS OF } \\
\text { NAIRA) }\end{array}$ & $\begin{array}{l}\text { INFLATION } \\
\text { RATE }(\%)\end{array}$ & $\begin{array}{l}\text { INTEREST RATE } \\
\text { LEADING }(\%)\end{array}$ \\
\hline Obs & $\mathrm{CU}$ & ELEC & GDP & INF & INT \\
\hline 1981 & 73.30000 & 1603.800 & 251052.3 & 20.90000 & 10.00000 \\
\hline 1982 & 63.60000 & 1775.400 & 246725.6 & 7.700000 & 11.75000 \\
\hline 1983 & 49.70000 & 1707.200 & 230380.8 & 23.20000 & 11.50000 \\
\hline 1984 & 43.00000 & 1804.800 & 227254.4 & 39.60000 & 13.00000 \\
\hline 1985 & 38.30000 & 2038.400 & 253013.3 & 5.500000 & 11.75000 \\
\hline 1986 & 38.80000 & 1331.800 & 257784.4 & 5.400000 & 12.00000 \\
\hline 1987 & 40.40000 & 1393.200 & 255997.0 & 10.20000 & 19.20000 \\
\hline 1988 & 42.40000 & 1404.200 & 275409.6 & 38.00000 & 17.60000 \\
\hline 1989 & 43.80000 & 1518.800 & 295090.8 & 40.90000 & 24.60000 \\
\hline 1990 & 40.30000 & 1656.000 & 472648.7 & 7.500000 & 27.70000 \\
\hline 1991 & 42.00000 & 1656.000 & 328644.5 & 13.00000 & 20.80000 \\
\hline 1992 & 38.10000 & 1847.000 & 337288.6 & 44.50000 & 31.20000 \\
\hline 1993 & 37.20000 & 1874.800 & 342540.5 & 57.20000 & 36.09000 \\
\hline 1994 & 30.40000 & 2013.600 & 345228.5 & 57.00000 & 21.00000 \\
\hline 1995 & 29.30000 & 1981.400 & 352648.6 & 72.80000 & 20.79000 \\
\hline 1996 & 32.50000 & 2025.000 & 367218.1 & 29.30000 & 20.86000 \\
\hline 1997 & 30.40000 & 2012.800 & 377839.8 & 8.500000 & 23.32000 \\
\hline 1998 & 32.40000 & 1881.800 & 388468.1 & 10.00000 & 21.34000 \\
\hline 1999 & 34.60000 & 1906.400 & 393107.2 & 6.600000 & 27.19000 \\
\hline 2000 & 36.10000 & 1944.400 & 412332.0 & 6.900000 & 21.55000 \\
\hline 2001 & 42.70000 & 2278.100 & 431783.1 & 18.90000 & 21.34000 \\
\hline 2002 & 54.90000 & 2250.200 & 451785.6 & 12.90000 & 29.70000 \\
\hline 2003 & 56.50000 & 2397.800 & 495007.1 & 14.00000 & 22.47000 \\
\hline 2004 & 55.70000 & 2762.300 & 527576.0 & 15.00000 & 20.62000 \\
\hline 2005 & 54.80000 & 2687.100 & 561931.4 & 17.90000 & 19.47000 \\
\hline 2006 & 53.30000 & 2650.200 & 595821.6 & 8.200000 & 18.70000 \\
\hline 2007 & 53.38000 & 2789.100 & 634251.1 & 5.380000 & 18.36000 \\
\hline 2008 & 53.84000 & 2845.900 & 672202.6 & 11.60000 & 18.74000 \\
\hline 2009 & 54.30000 & 2900.300 & 716949.7 & 12.40000 & 22.90000 \\
\hline
\end{tabular}

Source: Central Bank of Nigeria Statistical Bulletin (2009) 
Table 3. Model Representation of the Equations - Empirical Results

\begin{tabular}{|l|l|l|l|}
\hline Statistics & Model 1 & Model 2 & Model 3 \\
\hline Adjusted R-squared & 0.215072 & 0.885447 & 0.826892 \\
\hline R-squared & 0.299172 & 0.845354 & 0.796786 \\
\hline S.E. of regression & 0.212185 & 0.087050 & 0.099787 \\
\hline Sum squared resid & 1.125561 & 0.151553 & 0.229021 \\
\hline Log likelihood & 5.961484 & 33.33606 & 27.55575 \\
\hline Durbin-Watson stat & 0.548864 & 1.668933 & 1.115099 \\
\hline S.D. dependent var & 0.239497 & 3.753121 & 3.753121 \\
\hline Mean dependent var & 3.771792 & 0.221359 & 0.221359 \\
\hline Akaike info criterion & 0.135275 & 1.809719 & 1.611125 \\
\hline Schwarz criterion & 0.053318 & 1.429089 & 1.373231 \\
\hline F-statistic & 3.557359 & 22.08457 & 27.46627 \\
\hline Prob(F-statistic) & 0.028544 & 0.000000 & 0.000000 \\
\hline
\end{tabular}

Table 4. Augmented Dickey-Fuller (ADF) Unit Root test Statistics Summary Based on Mackinnon (1996) Critical Values.

\begin{tabular}{|l|c|c|c|c|}
\hline Variable & $\log \mathrm{a}$ & $\log (\mathrm{elec})$ & $\log (\mathrm{mf})$ & $\log (\mathrm{int})$ \\
\hline t-statistic & -2.1532 & -0.8091 & -3.5799 & -2.6187 \\
\hline $\mathrm{p}$-values & 0.2268 & 08010 & 0.0132 & 0.1012 \\
\hline Level of integration & $\mathrm{I}(0)$ & $\mathrm{I}(0)$ & $\mathrm{I}(0)$ & $\mathrm{I}(0)$ \\
\hline
\end{tabular}

Table 5. Unrestricted Co integration Rank Test (Trace)

\begin{tabular}{|c|c|c|c|c|}
\hline & & Trace & 0.05 & \\
\hline Hypothesized & Eigenvalue & Statistic & Critical Value & Prob.** \\
\hline No. of CE(s) & 0.675990 & 62.63667 & 47.85613 & 0.0012 \\
\hline None $^{*}$ & 0.532792 & 32.20822 & 29.79707 & 0.0259 \\
\hline At most 1 & 0.340369 & 11.66173 & 15.49471 & 0.1739 \\
\hline At most 2 & 0.015716 & 0.427700 & 3.841466 & 0.5131 \\
\hline At most 3 & & & \\
\hline
\end{tabular}

Trace test indicates 2 co integrating eqn(s) at the 0.05 level

* denotes rejection of the hypothesis at the 0.05 level

**MacKinnon-Haug-Michelis (1999) p-values

Table 6. WALD Coefficient Test Results

\begin{tabular}{|l|c|c|c|c|}
\hline Variable & C & $\log ($ Elec) & $\log ($ Inf) & Log (Int) \\
\hline Coefficient & 1.5176 & 0.43265 & -0.0195 & 0.3283 \\
\hline Probability of F Statistics & 0.2933 & 0.0307 & 0.7170 & 0.0212 \\
\hline Probability of Chi-Square & 0.2830 & 0.2220 & 0.7148 & 0.0139 \\
\hline
\end{tabular}

